It was supposed to be a poisoned arrow wound. Salerno was also distinguished as being the first schola to admit to its privileges and honours members of either sex. Its practice and its precepts as recorded in the famous "Regimen" seemed conservative to a degree, so that its liberality in the admission of women to its honours was the more remarkable. One Constantia Calenda achieved considerable fame. Salerno was the first schola to insist upon candidates pursuing a definite course of instruction before they obtained their degree. The examinations dealt with "verba" rather than "acta." Galen's "Therapeutics" and the first book of Avicenna, the "Aphorisms" of Hippocrates, and the "Analytics" of Aristotle were the staple. Before obtaining a qualification candidates were required to be 21 years of age. They were required to study arts and medicine for seven years. A would-be surgeon was required to study anatomy for a year. The oath was quite unlike the old Hippocratic one. Kveryone, to whatever degree admitted, had to swear " that he would take no fees from the poor nor have any share in the gains of the apothecaries. A book was put into his hand, a ring upon his finger, and a crown of laurel upon his head, when he was dismissed with a kiss from the learned doctors."

The rise and development of the earlier universities of Paris, Bologna, and others were then considered. The work of Mondinu=, the earliest work on anatomy to be illustrated by means of woodblocks, was compared with that of Vesalius. The lecture was illustrated by lantern slides copied from the oldest writers on anatomy and physiology.

\section{THE ANAMTAS OF INFANCY.}

\section{BY CLIVE RIVIERE, M.D., M.R.C.P. LOND.,}

ASGISTANT PHYSICIAN TO THE EAST LONDON HOSPITAI FOR CHILDREN,
SHADWELL; PHYSIOIAN TO OUT-PATIENTS AT THE CITY OF IONDON HOSPITAL FOR DISEASES OF THE CHEST.

IN the first two years of life anæmia of a slight grade not infrequently shows itself, mostly in association with rickets ; but every now and then cases of more advanced anæmia present themselves and, on account of certain peculiarities with which these cases are associated, they have had a separate label assigned to them and generally go by the name of "anæmia splenica infantum." Whether these cases belong to a class by themselves, and whether they have any claim to be considered a specific blood disease, we will discuss later. Let us first review them as they stand.

I have tabulated the blood conditions found in the 13 cases which have come under my notice, but space does not permit me to describe their symptoms in detail; I can only give a short résumé of those features which they presented in common. The clinical picture which they exhibit is closely similar in all the individual cases.

A child, most often between the ages of nine and 18 months, is brought for advice because it has been gradually losing colour and flesh and has become listless and apathetic. Occasionally the enlarged abdomen, or even the splenic tumour, is the first thing noticed. The onset has been insidious, there is always a history of digestive disturbance of some grade, and the child is nearly always hand-fed, generally injudiciously so. On examina tion the cbild shows considerable anæmia, with a lemonyellow, waxy skin; it is poorly nourished and its muscles are exceedingly flabby and toneless. There is nearly always rickets and that generally of a marked grade. The heart is somewhat dilated and there is often a soft systolic murmur at the apex or a hæmic murmur at the base. The abdomen is protuberant and tympanitic; the spleen is enlarged and firm, at times reaching nearly to the crista ilii; I have never felt a friction rub over it. The liver is large and rather firm, generally reaching one or two fingers' breadth below the costal margin. During the course of the illness the temperature shows irregular fluctuations, raised at night and normal or subnormal in the morning, though periods of apyrexia may intervene. The bowels are opened many times, sometimes seven or eight in the 24 hours; the stools are

I A paper rear before the Royal Medical and Chirurgical Society Nov. llth, 1903. of ten greenish and offensive; occasional vomiting is not uncommon. A hæmorrhagic condition in my experience is not common, even in fatal cases, only one of my own cases showing such, and that to a slight degree. The condition recovers if slight, or if more severe improves under careful reatment, but tends to relapse and the child often lingers a onsiderable time till a complication, either bronchopneumonia or one of the infective fevers, leads to a fatal The.

This represents an outline of the condition, but within this several interesting points occur and must be separately dealt with. First, the condition is distinctly more common among Jewish than other children; perhaps I should quality this and say Polish Jews, as most of my cases, and indeed most of the East-end Jews, belong to this nationality. For this reason the disease is the more difficult to study as post-mortem examinations are rarely to be obtained and the mothers are often with difficulty persuaded to leave their children for hospital in-patient treatment. It has been noted by some observers that twins are not infrequently affected; among my own cases neither twins nor, indeed, multiple cases in one family have occurred. With regard to the grade of rickets present, this has generally been viery marked and more especially has the cranial bossing been out of all proportion to any I have seen elsewhere and was present in marked degree in half my cases. This has been before remarked upon by Dr. J. S. Fowler ${ }^{2}$ in a paper read before the British Medical Association in 1900. In some of my cases there was also associated with this bossing some craniotabes in the occipital region, and these two conditions occurred apart from any syphilitic taint. In only one of my cases was congenital syphilis present. Enlarged glands are described by many observers; in only two of my cases were they present and they appeared to exert no influence upon the proportion of lymphocytes in the blood nor on the course of the disease. The disease is found in both sexes; in my own cases females preponderated in the ratio of 2 to 1 , but it does not seem probable that this is more than an accidental difference. Jaundice may occur during the course of the illness. Fowler ${ }^{3}$ records three instances among his cases. In one of my cases it was described in the history. I have since seen it in a case not included in my series; in this case it was obstructive in character and probably represents an accidental complication due to the gastro-enteric catarrh. When we speak of the gastro-enteric catarrh it brings us close, I think, to the etiology of the diseased condition in most of the cases. We will therefore postpone its consideration for the present.

\section{The Blood.}

The results of the blood examinations made in my cases are shown in the accompanying table. The counts were done with a Thoma-Zeiss apparatus, the hæmoglobin was estimated with von Fleischl's instrument, and the differential counts were made from films stained with Ehrlich's triacid stain after fixing with heat.

Red Cells - The red cells varied from $1,870,000$ to $3,720,000$ per cubic millimetre on first examination, the majority being just under $3,000,000$. From this they rose to normal under observation in a few cases. The colour index was always below the normal, which is about 0.8 in infancy; a common figure was 0.5 or 0.6 . When improvement took place the red count and the hæmoglobin generally rose together, leaving the colour index unaltered. The red cells showed much variation in size, very many cells smaller than normal and a few larger being present. Less alteration in shape was observable. Polychromatophilic changes could generally be seen even with the triacid stain. Nucleated red cells formed a striking feature and were present in all cases; they did not appear to bear any relation to the proportion of red cells present. The number falls noticeably as a case improves. Of these nucleated red cells a large proportion, from 20 to 40 or 50 per cent, were megaloblasts. A few microblasts were also present. The proportion of megaloblasts seemed to bear no relation to the severity of the case, nor does this proportion sensibly decrease or alter when improvement takes place. Their numbers are then reduced in the same ratio as the normoblasts.

Leucocytes - The number of leucocytes varied between 5000 and 38000 per cubic millimetre in my cases. All numbers between these two extremes were represented except that they were mostly above the normal 10000 to 12,000 per 


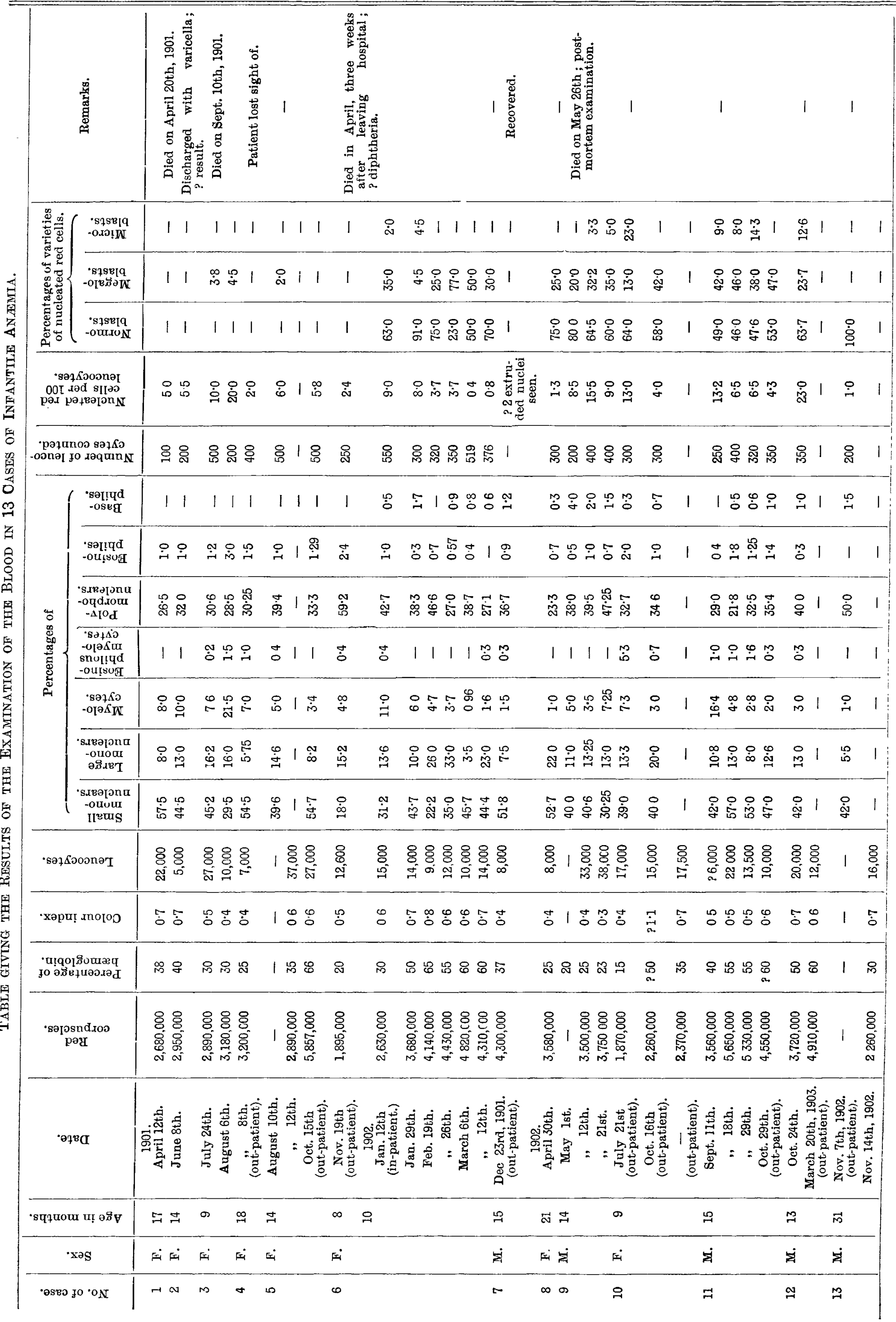


cubic millimetre of healthy children. The differential count in these cases presents considerable difficulty. First, among the non-granular cells it is very difficult to make any useful division into large and small, as should be done, of course, if we accept Ehrlich's conclusions as to their quite different origin. As a matter of fact, in this condition there is every grade between the smallest and the largest, the difficulty being caused by the occurrence of large forms of lymphocyte difficult to separate fro $m$ the normal large hyaline cell. For this reason I fear the division attempted in $\mathrm{my}$ table between them is purely arbitrary and it would perhaps lead to le:s error had they been grouped tngether. Another difficulty in some cases is in deciding between small myelocytes and polymorphonuclears, as transitional forms often appear which quite baffle classification. This probably accounts for the rather various myelocyte counts of different observers. The leucocytosis in these cases affects as much the lymphocytes as the polymorphonuclear cells, so that with an increase in absolute numbers they keep their relative proportions or thereabouts. It must be remembered that in infancy the proportion of lymphocytes is greatly in excess of that in adult life and they normally represent at least 50 per cent. of the leucocytes present. This may be due to the greater activity of lymphatic structures in infancy and early childhood. The eosinophiles increase or remain normal in this diseased condition as a rule, so that the proportic $n$ to the other cells is little changed. Mast cells are found but the detection of these with the triacid stain is so unsatisfactory that I do not claim much accuracy for the percentages assigned to them in my table. Besides these normal cells, in which a general increase occurs, an abnormal visitor, the myelocyte, appears in proportions varying from 1 or 2 to 20 per cent, 4 or 5 per cent. being a common find. Occasionally these cells are found bearing large granules, eosinophilous myelocytes, and in one of my cases as many as 5.3 per cent. of these appeared in the blood on one occasion.

And now, are we or are we not dealing with a specific blood disease? The best answer to this is another question. Is there any other form of marked anæmia recognisable in infancy? The answer I should make to that is-No. I nave never seen it, have vever found a description of such, and see no rea-on at present to believe in its existence. If cases of marked anæmia of quite another type do exist in the first two years of life they are very rare and must represent some specitic blood change, for the common aræmia of infancy is that which prigresses, when severe, to the picture of a so-called "anæmia splenica infantum." May I here remark that the age of two years which I have fixed as the limit of infancy is, so far as anæmia is concerned, no arbitrary point of time as might at first sight appear, for above this age the infantile anæmias rapidly disappear and examples of the adult anæmias begin to be recorded.

The marked anæmias of obvious causation, such as congenital syphilis, show all the charges claimed by some as peculiar to anæmia splenica infantum. I have at the present time under observation an infant, aged four months, suffering from congenital sy philis of unusually severe type. It presents to observation an interesting double picture : its "obverse" shows a typical severe syphilis with baldness, café-au lait skin, rash, snuffles, \&c. ; its "reverse" depicts an anæmia splenica infantum. The spleen and the liver are enlarged, as we should expect; examination of the blood shows $1,590,000$ red cells per cubic millimetre with 30 per cent. hæmoglubin, and 10,000 white cells per cubic millimetre the differential count of which is as follows : polymorphonuclears, 30.4 per cent. ; small mononuclears, 35 per cent. large mononuclears, 11 per cent. ; eosinophiles, 5 per cent. myelonytes, 17 per cent ; and eosino hilous myelocytes, 1.6 per cent. There are $3 \cdot 2$ nucleated red cells to every 100 white cells and of these more than a third are megaloblasts. Johann Lnos ${ }^{4}$ examined 16 cases of anæmia due to congenital syphilis with a similar result. All showed the blood changes characteristic of the so-called "aræmia splenica infantum," and Chailes Luzet ${ }^{5}$ describes similar changes in cases of anæmia following epiden,ic diarrbœa.

I would opine, then, that anæmia in infants, when sufficiently severe, always presents the peculiarities seen in these cases, the peculiar appearances noted in the blood and the enlargement of the spleen and the liver; or, to transpose it, that "anæmia splenica infantum" spells merely severe

4 Johann Loos: Wiener Klinische Wochenschrift, 1892. No. 20.

5 Luzet: Revue des Malades d'Enfance, 1891, p. 199. anæmia occurring in infancy, its peculiar characteristics eing due to the "infancy" factor rather than the "causation "factor. If this is so we should expect to find all grades of anæmia from the slightest passing insensibly into the more pronounced condition; and this $I$ hold that we may doevery grade in the anæmia, every grade in the splenic enargement, and every grade in the blood peculiarities from one myelocyte and one erythroblast in a differential count up to the large percentage of both found in the more advanced cases. The blood changes depend on the age of the child, not on any peculiar reaction to a specific causation. It must be admitted that though every grade may be found it is not so easy in practice to produce cases in intermediate stages, for this reason-either the anæmia clears up rapidly or it rapidly reaches an advanced stage, and once there a vicious circle, presently to be described, is set up and the patient remains for months in the condition described as anæmia splenica nfantum. It is difficult to say at what stage the nucleated ed cells, myelocytes, \&c., appear in the blood, though believe the anæmia must be fa rly advanced before this cccurs. Cases occasionally appear in which fairly marked anæula is found without the e blood peculiarities and such cases may be brought forward by some and contrasted with certain cases of so-called anæmia splenica infantum in which the anæmia is only slight but the blood contains nucleated red cells and myelocytes, to prove the specific character of these changes. I think the real explanation is that these first cases have not yet reached the stage at which the blood peculiarities begin and the cases with which they contrast ihem are anæmias which have been severe but are then recovering, the peculiar blood appearances remaining long after the anæmia has reached a quite mild grade.

And now, having denounced the specific causation of the condition, we are left to grapple with its etiology. I have already claimed indirectly that many causes may produce its peculiarities, being merely those of severe anæmia in infancy, and it seems probable that the proportions of those various factors which go to make up these peculiarities vary somewhat according to the causation at work. Indeed, it may be possible at some future time to determine this causation by slight variations in the symptoms present. I have mentioned syphilis as a cause but this, though occasionally present, is certainly not accountable for the bulk of the cases. 1 have already alluded to the gastro-enteric catarrh accompanying and preceding these cases and this is, in my opinion, the prime cause of severe anæmia in intancy and this cause can generally be traced back one step further-namely, to in judicious feeding. Of course the diarrhoa and vomiting will, by those who regard the disease as a specific anæmia, be considered only as part of the disease or as common complications thereof. I admit that once established the ar æmia, being a great causative factor of intestinal catarrh, tends to keep this going. Each reacts upon the other and this is that "vicious circle" to which I have alluded above ; but 1 hold that in most cases some catarrh can be shown to exist before the anæmia commences. Once this vicious circle is established it is difficult to prevent the downward progress of the case and it is this, I think, which tends to make rather a sharp line of demarcation between these cases of severe anæmia and the slighter grades in infancy ; once a certain point is reached recovery is very difflucult and they remain a long while in statu quo, the ready prey to those complications which so often hurry on the fatal issue. On the other hand, if this point is not reached they tend to recover rapidly and so the stages between are not largely represented clinically.

Among my own cases gastro-intestinal disorders formed an almost constant factor and they generally preceded the disease by a considerable interval. Only one of my cases had been breast-fed throughout; the others had been so fed generally for the first few months, just long enough to bridge over the time at which maramus so commonly occurs. Occasionally they had not been breast.fed at all. In all cases the subsequent feeding had been of a most undesirable nature. Among the Polish Jews, from whom more than half my cases come, breast-feeding is the rule and when this fails, as, fortunately for them, it seldnm does, they have even less idea of hand feeding than English mothers in the same class of life. This is sufficient, I think to account for the excessive proportion of Polish Jews among my cases, but to it may be added the fact that slight grades of anæmia also are very common among these children and seem to be very readily produced. In the first few months of life gastrointestinal catarrh leads to marked wasting, but in the later 
months of the first year, when the disease under consideration tends to appear, marked wasting less commonly shows itself than does rickets with poor nutrition and flabby muscles, so that these anæmias may be taken to correspond in later months to the marasmus of early infancy. In the early months the injured intestinal glands are unable to take up nourishment and the child starves; in the later months they have learned their function in this respect and take up not only nourishment but in addition toxins formed from the altered food substances. That rickets can be a cause of anæmia, or, indeed, of anything other than mechanical deformities, I cannot persuade myself to believe, being itself but a series of symptoms-a reaction of certain tissues to some cause or causes underlying it. That one of these causes-namely, gastro-enteric catarrh-may, at the same time that it causes rickets, also lead to marked anæmia, and that an anæmia of such a kind as has been described under the title " anæmia splenica infantum," I believe and hold. The rickets, in my opinion, in these cases runs parallel to the anæmia. The fdct that the anæmia may occur without rickets and that rickets is not necessarily associated with marked anæmia proves that neither depends on the other, nor can their causation be altogether identical.

1 And now, how does the intestinal catarrh act as a systemic poison? Intestinal toxins have been conjured up to explain so many varying conditions, and their appearance is so trite and convenient as a causative agent that it is with some shame and with many apologies that I drag them forward. If I could give you a table of their analysis-if I could show them on a plate-it would be very gratifying to me and very edifying to the Fellows of this society; but although this may not be done yet we cannot afford to ignore their formation. In cases of acute gastro enteritis in infants no one would have the hardihood to deny an absorption of toxins from the intestinal canal; when such a condition of toxin formation and ab. sorption goes on insidiously over a long period of time a different train of symptoms will be produced, a slow poisoning of the tissues, leading-why not?-to marked rickets and severe anæmia, the so-called anæmia splenica infantum. The organisms causing acute summer diarrhcez have yet to be definitely decided upon. Shiga's bacillus ${ }^{6}$ and various members of the coli group have been climed as such, and it seems probable that more than one organism, given favourable conditions, is capable of causing the symptoms of this disease. Similarly, in chronic catarrh, set up in the first place by unsuitable food, it is probable that the growth of organisms, differing, perhaps, according to the food supplied, may serve to keep it going, and that the products formed by their growth in these food substances, being absorbed, will cause a progressive poisoning of the human host. Once a suitable culture medium is prepared for them in the intestine there is no lack of organisms, either already present or introduced in food through the disordered stomach, to flourish upon it. Another possible source of poisoning remains to be mentioned-namely, toxins formed as the by-products of disordered digestion in these cases. And now, though we may not believe that we are dealing in anæmia splenica infantum with a primary blood disease, though we hold that those peculiar cells the occurrence of which is described above are readily called forth into the blood in infancy, still there must be a modus operandi under which they appear they are not there without cause, and since we believe that an intestinal toxæmia is that commonly at work it is interesting to attempt on those grounds some explanation of the changes observed. The views of Ehrlich as to the origin and destination of the blood cells seem to be those most widely accepted. It will therefore be convenient to base a working hypothesis on those views.

We have supposed a tcxin formed in the intestinal tract either by the action of micro-organisms on the undigested food-stuffs or as a by-product of disordered digestion. This, by its local action, will cause diarrhoea and vomiting and by the stimulation of intestinal lymphoid tissue will wash into the blood that increase of lymphocytes which commonly accompanies a gastro-intestinal catarrh in children. The poison circulating in the blood stimulates the bone marrow by an active chemiotactic reaction an increased supply of polymorphonuclears and eosinophiles takes place, causing a leucocytosis, perhaps with a view to belping in the formation

Duval and Bassett : American Medicine, Sept. 13th, 1902 ; Central blatt für Bakteriologie, \&c., Dec. 22nd, 1902. of antibodies to the poisons in the blood; but after a time this leucocytosis fails relatively, and to keep up the demand only partially formed granular cells, the myelocytes, antecedents of the polymorphonuclears, appear in the bloud. If this failure of leucocytosis is a fact, it should not be possible to cause a polymorphonuclear leucocytosis in one of these cases. I am not sure about this point. One of $\mathrm{my}$ own cases in an attack of pneumonia showed an increase of leucocytes generally but no relative increase (even a slight decrease) in polymorphonuclears. The leucccytosis having failed to overcome the poison, and the same being still formed, a destruction of red cells takes place, the spleen being enlarged partly to dispose of the refuse of these and the dying lencocytes.

That an increased destruction takes place seems to be supported by the following facts: 1. The presence of erythroblasts in the blood, suegesting an attempt on the part of the marrow to keep up the supply. The megaloblast present probably depend merely on the age of the patient, these being normally present in the marrow of infants. 2. The altered proportions between the young cells (large mononuclears and myelocytes) and the old cells (the polymorphonuclears) seem to point to increased destruction of the latter. 3. The alterations in size and shape of the erythrocytes may be due to a degeneration preceding their death. It might be argued, on the other hand, that these changes may be brought about by a poisoning of the bloodforming organs resulting in their inability to supply adult cells to the blood and so allowing immature forms to enter the circulation. If the increased destruction were great it might cause some increase in the iron content of the organs, especially of the liver if it occurred in the portal circulation, as one might expect in an intestinal toxæmia. If the destruction were in the general circulation, on the other hand, there might be no demonstrable increase of iron content in the abdominal viscera. In the only fatal case I have had in which a necropsy was permitted I got Dr. W. H. Hurtley to estimate the iron in the liver, the spleen, and the kidneys. He employed two methods for comparison and found in the spleen 0.01585 per cent., or 0.01818 per cent. in the liver 0.01527 per cent., or 0.01566 per cent. ; and in the kidneys 0.022 per cent., or 0.00287 per cent., or 0.0036 per cent. of iron as the result of three experiments with the two different methods. Dr. William Hunter ${ }^{7}$ among 20 collected analyses of normal organs found the iron content for the adult an average of 0078 per cent. for the liver and 0.171 per cent. for the spleen. The percentages in the child seem to correspond closely with these among the few analyses in infants I have been able to find. We see, therefore, that the percentages in my case of anæmia were low and, even allowing for an increased bulk of liver and spleen, do not point to any excess of iron in these organs such as occurs in the liver in pernicious anæmia. Does this mean that blood destruction plays no important part in this disease? I think not.

Let us glance at the condition in pernicious anæmia. In that disease Dr. Hunter has clearly shown that the blood destruction occurs in the portal circulation and the poison, intestinal in origin, as also the products of its action, the iron, \&c., never get beyond this point, but are dealt with by the liver before they reach the general circulation. But we have advanced the theory of an intestinal toxæmia in these anæmias of infancy also; how does it differ from that described above? Obviously in this, that in them the poison reaches the general circulation. The myelocytes and increased polymorphonuclears clearly point to a direct action through the blood stream on the bone marrow. We must thus suppose that the toxin, though entering the portal circulation, as in the case of pernicious anæmia, is not destroyed by the liver, but finds its way into the blood stream wholly or in part and there exerts its action on systemic structures. The blood destruction, if such exists, occurs in the general blood stream and its products are scattered broadcast instead of being seized and stored in the liver, as in pernicious anæmia. On the other hand, it seems quite likely that a deficient formation as well as a blood destruction is at work in this condition. That the blood-forming organs, and especially the bone marrow, are disturbed in this affection we have evidence in the unusual distribution of the leucocytes, and the relative deficiency of the hæmoglobin content of the red cells seems to point to the same and suggests a likeness to chlorosis in which a deficient production in all

\footnotetext{
7 Hunter : The Lancer, Sept. 22nd (p. 555) and 9th (p. 608), 1888.
} 
probability takes place, whether a dilution of the plasma is also present or not.

Three severe blood conditions in infancy have received recognition at various times in the past-anæmia splenica infantum, anæmia splenica pseudo-leukæmica of von Jaksch, and leukæmia. The first we have considered; when we come to a consideration of the other two we are met at the outset by a great difficulty-namely, the very imperfect blood examination made on the cases described.

Let us take leukæmia first, and by this term we mean spleno-myelogenic leukæmia, for it is this variety that the infantile anæmias resemble. What grounds are there for believing that spleno-myelogenic leukæmia occurs in infancy? It may be remarked at once that the grounds are narrow, but they are grounds it would be difficult to ignore. A fair number of cases have been described, but in almost all on quite insufficient evidence, and apart from one or two cases, in which the matter was more thoroughly proved by postmortem examination, one would be strongly inclined to discredit the occurrence of the disease at all in the first two years of life.

The most complete case $I$ can find is one described by von Jaksch ${ }^{8}$ in 1889. In this case, that of an infant, 14 months old, there was a progressive increase of leucocytes up to 192,000 per cubic millimetre at the time of death. At the necropsy the organs showed typical leukæmic changes and these were confirmed by microscopic examination. No differential count was made. Then comes a case recorded by Stilling, ${ }^{9}$ that of an infant aged 12 months, in which the organs showed definite leukæmic changes on the postmortem table. No blood examination was made. A third case is that recorded by Hochsinger and Schiff ${ }^{10}$ in an infant aged eight months ; it developed tumours of the skin, which microscopically showed a typical leukæmic infiltration. It appeared to be a mixed splenic and lymphatic leukæmia, but no post-mortem examination was obtained. Middleton's ${ }^{11}$ case, that of an infant aged 16 months, showed a leucocyte count of 370,000 per cubic millimetre (no differential count being made); but post mortem no naked-eye leukæmic changes in the organs were found, though microscopically the capillaries were found stuffed with leucocytes representing, perhaps, an early leukæmic infiltration. Dr. H. D. Rolleston and Dr. A. O. Latham ${ }^{12}$ have described the necropsy on a child 18 months old whose organs showed a similar change, but they seemed loth to consider it a case of leukæmia and on other grounds a diagnosis of lymphadenoma was made. In all the other cases I have been able to trace there has been some omission which has weakened their claim to be considered instances of this disease. In Morse's ${ }^{13}$ case, so often quoted, no post-mortem examination was made and there is, to my mind, nothing about the condition of the blood which clearly separates it from other cases of grave anæmia in infants. The myelocytes, it is true, rose to 21.4 per cent., but one of my own cases showed a myelocyte count of 21.5 per cent. and a larger eosinophile count than his. Perhaps I ought to have called this a case of leukæmia, but I could see no clear reason for doing so in the absence of a post-mortem examina. tion. Another of my cases which has improved considerably under treatment showed 16 per cent. of myelocytes. These represent all the cases I can find in infants under two years of age in which a claim for leukæmia was made. In children between three and four years old, an age somewhat beyond the limits of those anæmias with which this paper deals, a few cases also of leukæmia, both splenomyelogenic and lymphatic, have been described.

I think, then, we must allow that though rare and somewhat atyoical, as we shall see hereafter, cases which must be called leukæmia do occur in infants. In the year 1890 von Jaksch ${ }^{14}$ described some cases which he burdened with the somewhat cumbersome title of "anæmia infantum pseudo-leukæmica," and these he separated from leukæmia on the one hand and from splenis anæmia of infants on the other. They were cases in which a leucocytosis occurred out of proportion, he thought, to cases of so-called "splenic

8 Von Jaksch: Wiener Klinische Wochenschrift, 1889, Band ii., Ss. $435,456$.

Stilling: Virchow's Archiv, 1880, Band Ixxx., S. 475

10 Hochsinger and Sehiff: Vierteljahresschrift fïr Dermatologie und Syphil., 1887, Band xix., S 779

11 Middleton : Glasgow Medical Journal. 1893. vol. xxxix., p. 356

12 Dr. Rolleston and Dr. Latham : THE LANCET, May 14th, 1898, p. 1313.

13 Morse: Boston Medical and Surgical Journal, 1844, vol. cxxxi., p. 133. 14 Von Jaksch : Prager Medicinische Wochenschrift, 1890, Band xv.,
Ss. 403, 414. anæmia," but in which the post-mortem lesions of leukæmia were missing.

To recapitulate shortly the changes found in our cases of "splenic anæmia"-we have considerable anæmia, enlargement of the spleen and the liver, and, generally, advanced rickets. The blood shows a low red count with a still lower colour index. The leucocytes are moderately increased and a differential count among them shows myelocytes in fair numbers and many nucleated red cells, both normoblasts and megaloblasts. The cells normally present keep near the normal proportions of infancy.

Now how do these cases differ from those described by von Jaksch as anæmia splenica pseudo-leukæmica? Von Jaksch himself sums up the difference on three lines: (1) the smaller leucocyte count; (2) the absence of progressive increase of leucocytes; and (3) the presence of marked rickets. The leucocyte counts in his three cases at their highest were respectively $54,000,114,000$, and 36,000 per cubic millimetre. The latter two of these cases recovered and the count fell in one case from 114,000 to 10,000 per cubic millimetre in three weeks and in the other case from 36,000 to 12,500 per cubic millimetre in six weeks. In face of this fall and of the way in which the interval between the high and low counts is bridged over by intermediate cases surely the large leucocyte count cannot be sexiously quoted as a distinction between these cases and the splenic anæmia cases described above. If any here think that it can I should be very glad to learn at what number of leucocytes per cubic millimetre they would place the line of demarcation between them. As for the progressive increase of leucocytes, this may occur in fatal cases of all sorts and is not peculiar to von Jaksch's cases. Death depends upon persistence of the morbid condition, except when due to complications, and the leucocytosis runs parallel with this.

With regard to rickets, no very definite conclusion can be drawn. All my patients except one had rickets, most of them marked rickets, and I am disposed to regard the condition as a result of the same cause that produces the anæmia rather than as itself contributory in any way to the causation of the disease. The case in which there was no rickets differed in no respect from the other cases, either in history or symptoms ; moreover, in one of the patients in von Jaksch's three cases bad rickets is mentioned, so that this disease, since it is not always present in the one condition, and may be present in marked form in the other, can be taken neither to explain the one nor its absence to distinguish the other. Morse affirms the presence of rickets also in nearly all authentic cases of leukrmia which has some bearing on what follows.

It may be accepted, I think, that the difference between the cases described by von Jaksch as "anæmia splenica pseudo-leukæmica " and the cases of anæmia with enlarged spleen described above is one of degree only and not of kind.

And now the question arises: In what respect, if at all, do these cases of anæmia splenica differ from those of leukæmia mentioned above?

First, we do not find that the blood condition in these cases of leukæmia quite corresponds with what we should expect to find if we reason from the grounds of the same disease in the adult. In the adult we have an average of about 300,000 white cells per cubic millimetre, and of these about 30 per cent. are myelocytes; moreover, there is a definite increase of eosinophiles and mast cells. Now in healthy infants the leucocyte count is somewhat higher than in adult life and a leucocytosis is admittedly very readily set up and yet in these cases of leukrmia what do we find? Only 192,000 per cubic millimetre in von Jaksch's case at the highest and only 48,000 in Morse's case, whereas in older children quoted by Cassel and Baginsky at eight and nine years respectively there is no such failure in this respect, the leucocytes being 500,000 and 986,000 per cubic millimetre respectively. This alone, in the absence of a post-mortem examination, throws considerable doubt on Morse's case and the very moderate myelocyte count of 21.4 per cent. among these seems to confirm it. In Middleton's case, on the other hand, there were 370,000 leucocytes per cubic millimetre, a much more respectable number. In the other cases, unfortunately, the leucocytes were not counted-merely recorded as increased. More unfortunately still, we miss the advantage of a differential count in all but Morse's àoubtful case, for seeing the readiness with which myelocytes appear in the blood of infants (in dinhtheria, \&c.) and also the ease 
with which an eosinophilia is in them set up we should expect to see a very striking percentage of these two classes of cell in leukæmia. In Morse's case, as we have seen, there are only 21.4 per cent. myelocytes, a number which may be reached in fatal cases of anæmia splenica infantum and only 0.6 per cent. of eosinophiles, which represents no definite increase at all in such a comparatively small leucocyte count. In Rolleston's doubtful case the myelocytes numbered 20 per cent. and the eosinophiles 1.6 per cent, , but we do not know what absolute increase this represents as no blood count was made. In neither Middleton's case nor in von Jaksch's case was a differential count made but the latter informs us that there was no increase of eosinophiles. So that in those cases recognised as leukæmia in which a blood examination was made we find that the blood does not bear the characters we should have expected under the modifying influence of infancy.

Once more where do these cases of leukæmia differ from cases of spienic anæmia and von Jaksch's anæmia already described and where does the line of demarcation come, if such exist? That their appearance is strikingly similar is illustrated by the difficulty the older observers had in separating the two conditions; indeed, many of the splenic anæmias were described under the heading of leukæmia. Von Jaksch considers that the conditions can be separated clinically on several grounds.

1. He says that the liver is more enlarged in leukæmia than in splenic anæmia. What do we find on examining the facts? In von Jaksch's own case of leukæmia the liver was only just palpable below the ribs and after death it weighed 500 grammes, with a spleen of 430 grammes ; in my own fatal case of splenic anæmia, in which a postmortem examination was obtained, the age of the child was the same; the liver weighed 405 grammes, compared to a spleen of only 112 grammes-i.e., in my case of splenic anæmia the liver weighed nearly as much absolutely and relatively to the spleen much more than in his case of leukæmia. In Hochsinger and Schiff's case the liver was larger, reaching below the umbilicus; in Middleton's case the liver is definitely mentioned as not enlarged; in Stilling's case it is said to be rather large but no weights are supplied in Morse's case it came two fingers' breadth below the costal margin, so that the enlargement of the liver as a point of diagnostic importance between the two diseases appears to be of very little worth.

2. The second point von Jaksch states is that the eosinophiles are increased in leukæmia but diminished or absent in anæmia splenica. This increase in leukæmia is certainly what we should expect, but we have already seen that in leukæmia infantum they seem to be not necessarily increased, and in von Jaksch's own case he definitely states that no increase occurred. On the other hand, there is a fair percentage (generally about 1 per cent.) working out to a slight real increase, or at any rate no diminution, in the otber disease as illustrated by my own cases.

3. His third point is that anæmia is a more important feature among the cases of so-called anæmia splenica in. fantum than among cases of leukæmia in infants, but $I$ do not think that this distinction is of much value. One of my patients died without definite complications with a blood count of $3,750,000$ red cells per cubic millimetre and 23 per cent. hæmoglobin, another with $3,180,000$ red cells per cubic millimetre and 30 per cent. hæmoglobin; while in von Jaksch's own case of leukæmia the red cells fell to $2,310,000$ per cubic millimetre before death, in Middleton's case they were 3,300,000 per cubic millimetre, and in Morse's supposed case they were $2,900,000$ per cubic millimetre, so that there is really nothing to be said between the grades of anæmia in the two conditions.

And now comes the only distinction which appears of importance-the only line, as far as I can perceive, which can be drawn between the two diseases, and it is this : in leukæmia the organs are found after death to be infiltrated with leucocytes ; in anæmia splenica, on the other hand, they are not. Can this barrier be passed? Can we conceive that perhaps this, too, only represents a grade of disease, that anæmia splenica infantum is merely leukæmia which has never reached the stage at which infiltration of the organs occurs and that leukæmia merely represents an acute and advanced phase of the less serious-looking disease? I would advance the suggestion that we can. I cannot help thinking that cases will be found bridging over the gap between severe anæmia and leukæmia of infants-cases in which an infiltration of the organs is beginning to take place at the time of death-in which, though no alteration is observed in the organs by the unassisted eye, yet the microscope reveals the early beginnings of that change which in a more advanced grade causes the distinctive lesions of leukæmia. Are not Middleton's and Rolleston's cases illustrations of this commencing infiltration?

If we accept these contentions which I have laid before you to what do we commit ourselves? 1 . That severe anæmia in infants commonly presents the picture of so-called anæmia splenica infantum or of anæmia splenica pseudo-leukæmica and that the causation of such severe anæmia is generally an absorption of intestinal toxins. 2. That if the condition is more severe, probabiy from a somewhat more acute poisoning, the picture of leukæmia infantum is producedi.e., that leukæmia in infants is nothing more than the most advanced example of a morbid condition represented in its pre-leukæmic stages by the conditions known as anæmia splenica infantum and anæmia splenica pseudo-leukæmica of von Jaksch.

So far it looks easy, but other issues must be reconciled. Some may object that leukæmia is a very fatal disease, whereas recovery takes place from the slighter cases of anæmia splenica. This should not disturb us. Children react very differently to various diseases than do adults, and because leukæmia runs a well-recognised course and is almost certainly fatal in later life there is no reason why the same should obtain in infancy. The mortality, moreover, be it noted, is by no means low among marked cases of splenic anæmia (so-called). More than half of the patients among my own cases are already dead and others are likely to follow. I can only record two recoveries as yet among my 13 cases.

The next point we are met with is the comparative frequency of leukæmia, or rather its antecedent anæmias, in infancy, and this is what we should expect if its causation is not specific. It represents the natural reaction of the blood-forming organs in infancy to various poisons, and in this respect may be compared to broncho-pneumonia which is also commoner in infancy than in adult life and is the result in the infantile lung of the inroad of many different organisms.

And now we have broken the ice of the next somewhat startling conclusion to which our arguments have necessarily led us-namely, that leukæmia in infancy is not a specific disease. Something needs to be said on this head. Naturally the slighter causes of anæmia in infants would not be expected to lead to a leukæmic condition; it is to the serious anæmias only that it is closely related. These serious cases, I would suggest, are always intestinal in origin and if the poisoning is severe enough a leukæmia may be the result. Obviously there is something peculiar about this poison ; it must be produced continuously over a long period of time and it must be capable of escaping the vigilance of the liver either directly or by entering the blood through the lymph stream. In health the liver has the power of absorbing poisons carried to it in the portal circulation and of returning them to the intestine in the bile. The poison of pernicious anæmia seems to be caught in this way and exerts its influence on the blood in the portal circulation only.

On the other hand, it seems probable that many poisons are capable of evading this action of the liver, as is exemplified by cases of acute gastro enteritis in infants. Here the symptoms of a general toxæmia are rapidly established and it seems certain that similar symptoms may be cansed by the action of more than one organism in the intestine. If this is so in cases of acute poisoning I think we are bound to admit that in the chronic poisoning which leads to anæmia or leukæmia no specific organism need be pressed into service but many may be capable of causing it. This contenticn becomes more difficult when we turn to leukæmia in the adult. Here we see none of those slighter forms, none of those pre-leukæmic stages from which recovery may take place ; it is either " neck or nothing." This fact makes it evident that the causation in adults is considerably narrowed, that but few organisms can form poisons capable of originating the disease, and that a peculiar environment is necessary for their growth. The disease is rare. Moreover the blood-state is for the adult, though not for the infant, something quite peculiar and specific; it is no less than a return to the condition of an infantile anæmia. How can this be explained? We have dismissed the specific character of the blood changes in infantile anæmia as untenable, though we have nevertheless claimed that an 
intestinal toxæmia is the common cause of the condition-of the severe cases and leukæmia probably the only cause. But if the blood changes are not specific and depend merely on the "infancy" factor, how can these same changes be brought about at the call of a diseased condition in adult life?

For an explanation of this let us turn for illustration to another disease of infancy the peculiarities of which are exhibited less frequently in adult life-namely, broncho-pneu. monia. It must be understood that I use broncho-pneumonia as a convenient illustration only and do not claim it as a parallel to the disease $I$ am discussing. I am well aware that the occurrence of broncho-pneumonia in infancy depends largely on the physical peculiarities of the infantile lung and is therefore not directly comparable to a tissue reaction such as that we are discussing. At the same time the illustration may be closer than at first sight appears, since the prevalence of the "leukæmic" anæmias in infancy may also depend to some extent on a physical factor-the infantile intestine in place of the infantile lung.

Acute broncho-pneumonia is essentially a disease of infancy and can be caused by any of several organismspneumococcus, streptococcus, staphylococcus, diphtheria bacillus, influenza bacillus, \&c. The pneumococcus, as we know, is by far the commonest cause. It is often present in the throat in health and only awaits certain conditions favourable to its growth to set up the disease. To adults the pneumococcus is a much less formidable enemy and if it does gain an entry causes, not broncho-pneumonia as in infancy, but a somewhat different morbid condition-namely, croupous pneumonia. But broncho-pneumonia also occasionally occurs in adult life, though it is a disease of infancy. The pneumococcus does not cause it but the influenza bacillus, a very rare cause in infancy, in adult life readily sets up a typical broncho-pneumonia.

Let us apply the above facts to illustrate what may occur in leukæmia. The leukæmia of adults, though it displays certain noticeable differences, bears a close resemblance in its blood changes to leukrmia and the severe anæmias of infancy and may be considered to be, I think, a return to an infantile condition. This condition of blood is comparatively common in infancy, representing the natural reaction at this early age, and like broncho-pneumonia might be caused by the poisons of many different organisms (intestinal), of which probably one (like the pneumococcus in broncho-pneumonia) is more communly active than others. After infancy is passed the tendency to this blood reaction is passed also, but still the condition may occasionally be set up in adult life. Like broncho-pneumonia fewer organisms (possibly only one) may, developing in the intestine, be able to cause it in later life and that perhaps a different one (compare adult influenzal bronchopneumonia) from that which commonly sets it going in infancy (compare pneumococcal broncho-pneumonia). Thus, though leukæmia (including the pre-leukæmia anæmias), being only the natural reaction to various poisons, may not be considered specific in infancy, yet in adult life it may become specific in that the blood changes are quite peculiar when compared with other adult blood conditions and its causation is so narrowed down as to be practically solitary.

I would, then, sum up my conclusions as follows :-

1. That anæmia from any cause in infancy if severe enough gives rise to the peculiar symptoms grouped under the headings "anæmia splenica infantum" and " anæmia splenica pseudo-leukæmica" of von Jaksch.

2. That, consequently, these are not specific blood diseases but owe their "peculiarities merely to the "infancy factor" and that they represent merely different stages of the same condition.

3. That the common cause of severe anæmia in infants is gastro-intestinal catarrh, leading to the absorption of toxins either from the growth of micro-organisms or possibly from the formation of poisonous by-products of digestion.

4. That leukæmia of infants is not a separate disease, but merely a still more advanced stage of this anæmia-that is, that the difference between them is one of degree and not of kind.

5. That leukæmia of adults is a return to the condition of an infantile anæmia and that, being rare, its causation is probably so narrowed down as to be practically specific.

In conclusion I would like to express my thanks to my colleagues at the East London Hospital for Ohildren for their kindness in supplying me with opportunities for studying those cases which came under their care.

I feel also that an apology may be expected from me by you, gentlemen, for having placed before you so much theory to-night and so few new facts. If it is expected $I$ offer it in all heartiness; at the same time I cannot but feel that an attempt, however inadequate, to reason from facts already accumulated and to build up a working hypothesis upon them should have as much claim to your consideration as the mere accumulation of those facts themselves. If we could believe that leukæmia in infancy merely represents a severe grade of so-called splenic anæmia and that leukæmia in adults is a return to a condition of infantile anæmia it might, I venture to think, bring us a step nearer to the comprehension of this interesting disease.

Devonshire-street, $\mathrm{w}$.

\section{A CASE OF MULTIPLE LIVER ABSCESS.}

BY ANDREW BALFOUR, M.D., B.Sc., M.R.C.P. EDIN., D.P.H. OANTaB.,

DIREGTOR, WELLCOME RESEARCH LABORATORIES, GORDON COLLEGE, KHARTOUM,

THE following case of multiple liver abscess appears to me worthy of being placed on record for the following reasons : 1 . The comparative rarity of the site of the larger abscess and the somewhat infrequent nature of the smaller. 2. The apparent absence of dysentery as a forerunner. This is seemingly no uncommon occurrence in the Sudan where I believe that in cases of hepatic abscess a history of dysentery is rarely obtainable. 3 . The possibility that the affection of the liver was antecedent to a dysenteric attack which was cut short by the fatal issue of the case. 4. The great rapidity of the course of the disease and the absence of symptoms pointing to the full gravity of the condition. 5. That a fatal result followed exploratory puncture, a very rare event to judge by reports given in the literature of the subject. 6. There was some question as to the real nature of the pathological condition.

In the month of June, 1903, I was called in consultation to see a medical officer of the Egyptian army, a surgeon of repute with an extensive knowledge of tropical surgery, a point of importance in the case, as will be seen. He had been ailing for three days and the facts to be noted in the history given me were as follows. The patient was a strongly built man, 29 years of age, though he looked older, of dark complexion, a very typical Celt, extremely temperate, accustomed to plenty of exercise, and with a record of four years' medical work in Egypt and the Sudan. He had never suffered from malaria, enteric fever, dysentery, or, indeed, any serious malady. At a later date I learned that a year previously his blood had been examined for the hæmamoba malariæ with a negative result, but that eosinophilia was present at that time. He had never, however, had any symptoms pointing to an infection by metazoal parasites. He was always most careful to avoid taking chill, constantly wearing a cummerbund and possibly carrying his precautions almost too far, as he rather burdened himself with clothing. Immediately prior to his illness he had been overworked. In addition to his ordinary duties, which were sufficiently arduous, he had been studying hard for an Arabic examination and in consequence had been unable to take his accustomed recreation in the shape of golf or riding. For some little time he had been looking fagged and it is worthy of note that a few days before he became really unwell he had been attending a case of slight dysenteric diarrhcea in the house in which he himself lived and slept. At the time he fell ill a case of bad enteric fever was also under his charge. It should also be mentioned that just prior to his illness his nose had been cauterised with chromic acid for a hypertrophic condition of the mucons membrane. On the night preceding the day on which he first complained he had been out at dinner and was then very cheerful and lively-in fact, he seemed to be in excellent spirits. He partook of a good deal of iced, non-alcoholic drink and stated afterwards that he felt it very cold on the stomach and feared it might have given him a chill. The following morning he felt seedy, complained of nausea, flatulence, and some pain in the epigastrium. He had no diarrhoea but his temperature 